\title{
The Classroom Character Education in English Lessons Based on the 2013 Curriculum
}

\author{
Putu Mila Romana Dewi ${ }^{1 *}$ iD \\ ${ }^{1}$ English Language Education, Ganesha University of Education, Singaraja. Indonesia
}

*Corresponding author: Miladewi978@gmail.com

\section{Abstrak}

Moral dan karakter bangsa Indonesia semakin menurun. Hal ini dibuktikan dengan banyaknya kasus kekerasan, seksualitas, narkoba, cybercrime, bullying. Beberapa siswa juga melakukan tindakan menyimpang seperti menyontek dan merokok. Penelitian ini bertujuan untuk menganalisis praktik pendidikan karakter dalam pembelajaran bahasa Inggris. Jenis penelitian ini adalah kualitatif. Metode yang digunakan untuk mengumpulkan data adalah observasi, wawancara, dan angket. Instrumen yang digunakan dalam penelitian ini adalah pedoman wawancara, pencatat, daftar periksa analisis RPP, dan daftar periksa observasi. Teknik analisis data yang digunakan adalah analisis deskriptif kualitatif. Hasil penelitian menunjukkan bahwa guru telah memasukkan nilai-nilai karakter dalam RPP yang terdapat pada indikator, materi pembelajaran, langkah-langkah pembelajaran, instrumen penilaian, dan proses belajar mengajar. Selanjutnya, topik dan indikator pembelajaran mempengaruhi perbedaan nilai karakter yang terkandung dalam proses pembelajaran. Sedangkan penilaian pendidikan karakter dalam proses belajar mengajar yang digunakan guru adalah investigasi berupa rubrik nasehat dan penilaian. Penelitian ini mengandung makna bahwa guru dapat menanamkan nilai-nilai karakter pada siswa sehingga dapat membentuk karakter siswa yang unggul.

Kata kunci: Pendidikan Karakter, Pelajaran Bahasa Inggris, Kurikulum 2013, Nilai

\section{Abstract}

The morality and character of the Indonesian nation are decreasing. This is evidenced by many cases of violence, sexuality, drugs, cybercrime, bullying. Some students also commit deviant actions such as cheating and smoking. This study aims to analyze the practice of character education in learning English. This type of research is qualitative. The methods used to collect data are observation, interviews, and questionnaires. The instruments used in this study were interview guides, notetakers, lesson plan analysis checklists, and observation checklists. The technique used to analyze the data is descriptive qualitative analysis. The results showed that the teacher had inserted the character values in the lesson plans contained in the indicators, learning materials, learning steps, assessment instruments, and the teaching and learning process. Furthermore, learning topics and indicators affect the differences in character values contained in the learning process. While the assessment of character education in the teaching and learning process used by the teacher is an investigation in the form of an advice and assessment rubric. This research implies that teachers can instill character values in students so that they can form superior student characters.

Keywords: Character Education, English Lessons, 2013 Curriculum, Values

\begin{tabular}{|c|c|c|}
\hline History: & & Publisher: Undiksha Press \\
\hline Received & : February 04, 2021 & Licensed: This work is licensed under \\
\hline Accepted & : March 30, 2021 & (c) (†) () \\
\hline
\end{tabular}

\section{Introduction}

Through the globalization, morality and character of the nation increasingly decreased in Indonesia (Mahardika, 2017; Suryaningtyas, et al., 2014). The most common case related to violence against all aspects of sexuality, drugs, cybercrime, bullying and so on (Fitriani \& Marlina, 2017; Muhammad, 2019; Wiasti \& Arjani, 2021). The observations made at SMP Negeri 1 Seririt found that there were some deviations in class VIII students at this school, such as cheating, smoking, and one of the students had a tattoo on the body. This proves that the Student Association's environment is not in good condition. For school students, this is not allowed because it can interfere with the learning process. They also harm social and learning processes. Other students may be influenced and do things that are not of good character. The 
results of this study aim to provide innovative models in the implementation of character building.

Currently, the government seeks to find solutions to reduce and mitigate the adverse impact that will occur. One of the efforts that being implemented is implementing the Curriculum 2013 which is program based on character education. This is because the curriculum plays an important role in education. In line with this, the insertion of character enhancement is a part of the curriculum application (Mahardika, 2017; Suryaningtyas et al., 2014). In its implementation of curriculum 2013, character education is mandatory to be integrated into the learning and teaching process by the teacher. The difficulty is to determine the exact model that will be inserted good character values. It is the model that promotes the characters value in the class session. So, the teacher adjusts the value of the characters which is inserted with the specific subjects especially through the English lesson. The goal is to facilitate the achievement and effectiveness in the application of character-based education curriculum. Besides that, the purpose is to build a good condition of the school atmosphere through a good attitude and habits. Relevant with that, Character education leads to the establishment of school culture, which underlines the attitudes, traditions, habits, and symbols practiced by all stakeholders of the school and its surrounding communities (Kuswara \& Sumayana, 2020; Widiyasanti \& Ayriza, 2018).

Character education in principle is an action to develop students' behavior in terms of emotional, social and ethical (Dalimunthe, 2015; Sriyanto, Leksono, \& Harwanto., 2019). Referring to the principle, it can be seen that character education is a reference to direct students in order to build sensitivity to social circumstances around, have a sense of responsibility and always uphold good ethics. It's application in learning, character education serves to support the cognitive balance of both abilities and soft skills. Along with this, character education as an academic balancing that is a result of a joint mission to be noticed in learning (Narayani, 2019; Winaya, 2018). In the application of character education in the curriculum of 2013 emphasizes students on the wisdom and internalization of spiritual values. Character education leads students to learn and to understand wisdom in life also in spirituality (Maunah, 2015; Wuryanti, 2016). Wisdom is one of the things that need to be introduced to students from an early age. This is in accordance with the essence of education which is basically an imitation and habituation. The goal is to form a pattern of wisdom or wisdom and a pattern of spiritual maturity. In accordance with the core competencies of the first curriculum of 2013, which expects students to have an attitude of respect and internalize religion as well as the second core competency that expects students to be able to implement honesty, discipline, responsibility, care and confidence in the community (Veronika, 2019; Wulandari \& Suparno, 2020).

One of the subjects that have been concerned in education in Indonesia is English. English has been familiar to students since it has been introduced from the basic education level. English became one of the means of implementing character education in learning. Therefore, English is one of media in the form of language that can transfer the moral value through the communication (Prastikawati, Wiyaka, \& Budiman, 2021; Zuhriyah, 2017). The Humans connect with communicating through the language. Through the language human can touch each in the term of building responsibility. If the responsibility is positive, so it can guess that there is a good character through the language because a good character leads the language user do communication in a good-manner (Basri, 2018; Mulyanah, Ishak, \& Iqbal, 2018). So, there is good relationship through a good language in the communication that signifies the implementation of a good character value as well. The character values that will be integrated should be incorporated into the lesson plan previously designed by the teacher (Chairiyah, 2014; Supraptiningrum \& Agustini, 2015). In relation to the learning of the 2013 curriculum, the learning plan serves as a tool for guiding the combination of character values 
and other aspects needed in the lesson especially for cognitive and affective goals of the students (Darmansyah, 2014; Wahyudin, 2018). The next step is to adapt lesson plans in the learning process by adjusting the learning steps, indicators and assessment methods. So, it is impoartant to implement the moral value through the lesson by the teacher in order to give understanding about how significant good character among students. The findings of previous research stated that character education values could improve students' character (Danny, 2013; Wisnu \& Komang, 2019). Previous research findings also stated that planting good character will create special student characters (Harahap, 2019; Wuryani \& Yamtinah, 2018). There is no study of character education in English lessons based on the 2013 curriculum. The purpose of this study is to analyze character education in English lessons based on the 2013 curriculum. It is hoped that this research can help teachers to instill character education in students.

\section{Methods}

This qualitative research was conducted by descriptive qualitative research with natural setting and data. There are five characteristics of qualitative research. The first one is the key instrument that consists of the ordinary situation as a direct source of data and the researcher. In the implementation of this research, the researcher observed the class from the back of the class. Temporarily, the students have been used to being observed and it makes there is no effect from the researcher's presence to the natural situation of the class. The second one, the qualitative research is in the form of the descriptive trough the form of words or picture as the data collected. Three, the process is the main concern in this study rather than the product. The data is inductively analyzed. Fifth, the essential thing to qualitative research is "Meaning". Those characteristics of qualitative research were used to analyze and describe the employment of character education in the classroom depend on the 2013 curriculum by English teacher of eighth-grade students at SMP N 1 Seririt. One of English Teacher in that school was analyzed concerning the employment of character education in English lesson depends on 2013 curriculum. The methods used to collect data are observation, interviews, and questionnaires. The instrument used to collect data is an interview sheet. The technique used to analyze the data is a descriptive qualitative analysis.

\section{Results and Discussion}

Based on the result of the lesson plans analysis, there were several characters programmed to be employed by the teacher that was found by the researcher. Start from the first lesson plan, the values of politeness, discipline, and religiousness were available in the pre- activity. Some lesson's activity namely greeting, praying, monitoring the student's presence, and the study's focuses. While, in the mid-activity, the characters of hard work, logical thinking, honesty, curiosity, independence, cooperative, responsibility, creativeness, and confidence were programmed by the teacher. The teacher also programmed to make a conclusion, to make evaluation through the learning process, give homework as the stabilization activity for the students at their home, and finally close the instructional activity. Hereabouts, the planning also consisted of appreciativeness and politeness. Furthermore, the teacher programmed some activity namely greeting, praying, monitoring the student's presence, and demonstrating the study's focuses on the pre-activity of the second lesson plan. The teacher implanted the character values of religiousness, politeness, and discipline in this activity. Meanwhile, the teacher programmed the responsibility, carefulness, creativeness, curiosity, independence, friendliness/communicativeness, logical thinking, appreciativeness, hard work, honesty, and confidence as the characters in the mid-activity. After that, the 
teacher programmed the values of politeness, independence, friendliness/ communicativeness and honesty at the end of the lesson's activity or the post- activity. The characters values also mentioned by the teacher in the lesson plan's indicator. Moreover, the elaboration of character values in the teaching material, assessment and learning activity the researcher by the researcher.

In this section, the researcher did the observation to perceive the employment of character constructing in English instructional. Those observations were directed to two meetings using different material in the same class. the observation in $8 \mathrm{~B}$ class, started with a spoken and written text as the topic of the first meeting to affirm and ask the capability and the readiness to do an action. The character values of politeness, hardworking, discipline, independence, curiosity, confidence, rational thinking, honesty, appreciativeness and friendliness/communicativeness were taught during this meeting. Lead by the expression to give and respond the instructions and invitation as the topic of that second meeting. In the process of these meetings, the character values of politeness, logical thinking curiosity, friendly/ communicative, independence, honesty, confidence, hardworking and discipline was taught by the teacher.

Table 1. The Character Values that were implemented in the second observation

\begin{tabular}{lll}
\hline Pre-Activity & Whilst-Activity & Post-Activity \\
\hline Politeness & Curiosity & Appreciativeness \\
Discipline & Hard work & Honesty \\
Creativeness & Independence & Politeness \\
Confidence & Confidence & \\
& Friendliness/communicativeness & \\
& Logical Thinking & \\
& Respect & \\
\hline
\end{tabular}

Those Tables 1 that there were several different character values that were implemented in the classroom and that were planned in the lesson plan. By analyzing the lesson plans that teacher brought through the checklist, observed through the observation checklist, and also interview, the data were gained. Based on the findings prior, there was three point that has described by the researcher namely character education values that were implanted in the lesson plant, also the character values that were applied in the instructional process and the teacher's technique in assessing student's character education values. In addition, the character education's values that were implanted in the lesson plan, the character education values that were applied in the instructional process, and the student's education values will be described more specifically in the next discussion.

According to the result or the findings, the character education's values have been inserted into the lesson plan by the teacher. The character values consist of religiousness, creativity, responsibility, confidence, logical thinking, independence, politeness, carefulness, friendliness/communicativeness, honesty, discipline and curiosity that were implanted in the lesson plan. In their lesson plan, the teacher also implanted the character values into the indicators such as tolerance, love of peace, confidence, politeness, discipline, honesty, communicativeness and responsibility. This positive character value will shape the character of superior students (Ibrahim, Kuswidi, \& Arfinanti, 2020; Koesoemadinata, 2018). Besides that, the character values also implanted in the learning materials. Start from oral and written text as the topic of the first lesson plan to affirm and ask the capability and the readiness to do an action while those values were implanted in the form of word and phrases. The character values consist of social care, communicativeness, and honesty that were implanted. Then in the second lesson plan that leads to the expression to give and respond the instructions and 
invitation as the topic. The character values were implanted in the material of the learning. The character values consist of four-character namely honesty, politeness, communicativeness, and social care (Chairiyah, 2014; Sutarto, 2017). Those character values are known through the uses and the content of the materials because those were implanted in directly and indirectly (Suhaida \& Fadillah, 2019; Supraptiningrum \& Agustini, 2015).

The character education's values were applied in the instructional process. It means that the character education's value also applied through the teaching and learning process in the classroom (Indiarti, 2017; Wuryanti \& Kartowagiran, 2016). In addition, there are tree activities namely pre-activity, whilst-activity, and post- activity that should be done. The researcher separated the data appropriate with the teacher's techniques to teach those character values in order to investigate the data. Some of the values were implicitly intrinsic in activities through the student's question to do something that finally established by the teacher. While some other was demonstrated and taught through the direct statement. Moreover, the applied of character values were not appropriate with the character that planned to be applied. Appropriate with the findings, several activities that the teacher did in combined the character values in the instructional process which currently did not realize by most of the students. Instead, the characters which become aims and listed on the lesson plan did not clearly say. According to the observation, the teacher used advice and scoring rubric to assess the student's character as their strategy. The findings proved that character building have already applied in the classroom by the English teacher of SMP N 1 Seririt. Some of them did not match with the character values that planned to be applied. It means that some of the character values were successful to be applied and the other was failed.

Nowadays, there is a strategy to form the character of the student in the classroom. That is by using a comprehensive approach which is consist of nine things that the teacher has done (Cahyono, Tsani, \& Rahma, 2018; Damanik \& Setiawan, 2016). In the fact of this study, two of them were done by the teacher namely teach values through curriculum and use cooperative learning. The first one was teaching the character values through the curriculum that lead to the reality that teachers are obligated to combine character education into their instructional process following this 2013 curriculum. This study clarified that the teacher implanted the character values in planning, applied the character values in the classroom, and assessed the progress of students' character (Darmayasa, Jampel, \& Simamora, 2018). The values were implanted by the teacher through the indicator, learning material, instructional step, and evaluation. Meanwhile, the teacher used the scoring rubric and gave instruction for the student in order to assess the student's character. The second one was to use cooperative learning that leads the teacher asked the student to do the learning activities together with their friend in this study. By leading the student to work in a pair the teacher hoped the work could be completed together besides helping each other to understand the material and solve the problem.

Character education is the important thing in order to construct a good generation. It is not easy to build the human beings character with the aim to produce a good generation (Hidayah, 2015; Rosikum, 2018). This is because of the long process that needed. In other words, it was one of the difficulties in implementing and modifying the character value into the lesson plan. The lesson plan is the important tool because it's extremely useful to attend an integration guide, reserve, and historical document in teaching (Mastra, 2019; Wikanengsih, Nofiyanti, \& Permana, 2015). It means that it would be difficult to achieve the student's character if the teacher did not modify the instructional steps. It also inhibits the main purpose of constructing good character education. The other important thing is making the students realize that they are in the process of character building beside others approaches are needed (Kuswara \& Sumayana, 2020; Utomo, 2018). The students are able to evaluate themselves in the process of constructing the character building through the instructional. 
Indeed, the teacher has a significant role to sustenance the success of the character building (Ratnawati, Imron, \& Benty, 2018; Rispantyo, Anita Trisiana, 2019). In accordance with the findings and discussion, the researchers can conclude that the teacher was still using the way of teaching which is commonly used by other teachers in general. There was no other special way to apply the character education in SMP N 1 Seririt. Besides to teach the student and lead them to have a good manner, character education is also naturally happened to someone as the habituation that can be formed by modifying or construct good habits among student.

\section{Conclusion}

The teacher has implanted character values through the lesson plans in indicators, learning material, learning activities, and assessment. there were three activities that should be done by the teacher namely pre- activity, whilst- activity, and post-activity which is all contain character values that were implanted by the teacher. Moreover, the character values were different in each meeting. Indeed, some of the values failed to be applied in classroom and some values that successful to be applied were beyond the lesson plan. In other words, some of the values planned and the values applied in the classroom didn't match. Based on the findings, it was evident that character education has already applied by the English teacher of SMPN 1 Seririt during the instructional process in the classroom.

\section{References}

Basri, H. (2018). Strategi Belajar Kosakata Bahasa Inggris (English Vocabulary). Strategi Belajar Kosakata Bahasa Inggris (English Vocabulary, 11(2), 432-444. https://doi.org/http://dx.doi.org/10.19105/nuansa.v11i2.540.

Cahyono, B., Tsani, D. F., \& Rahma, A. (2018). Pengembangan Buku Saku Matematika Berbasis Karakter pada Materi Trigonometri. Jurnal Phenomenon, 08(2), 185-199. https://doi.org/http://dx.doi.org/10.21580/phen.2018.8.2.2929.

Chairiyah. (2014). Pendidikan Karakter Dalam Dunia Pendidikan. Literasi: Indonesian Journal Of Humanities, 4(1). Retrieved from https://jurnal.unej.ac.id/index.php/LIT/article/view/6216.

Dalimunthe, R. A. (2015). Strategi dan Implementasi Pelaksanaan Pendidikan Karakter di SMP N 9 Yogyakarta. Jurnal Pendidikan Karakter, 1(1). https://doi.org/https://doi.org/10.21831/jpk.v0i1.8616.

Damanik, M. R., \& Setiawan, D. (2016). Pengembangan Penilaian Autentik Berbasis Karakter Pada Ranah Keterampilan Di Fakultas Ilmu Sosial Universitas Negeri Medan. Jurnal Pendidikan Ilmu-Ilmu Sosial, $8(2)$. https://doi.org/https://doi.org/10.24114/jupiis.v8i2.5150.

Danny. (2013). Pembentukan Karakter Anak Melalui Kegiatan Mendongeng. Jurnal Humanika, 17(1). https://doi.org/https://doi.org/10.14710/humanika.17.1.

Darmansyah, D. (2014). Teknik Penilaian Sikap Spritual dan Sosial dalam Pendidikan Karakter di Sekolah Dasar 08 Surau Gadang Nanggalo. Al-Ta Lim Journal, 21(1), 1017. https://doi.org/10.15548/jt.v21i1.67.

Darmayasa, I. K., Jampel, N., \& Simamora, A. H. (2018). Pengembangan E-Modul Ipa Berorientasi Pendidikan Karakter Di Smp Negeri 1 Singaraja. Jurnal Edutech Undiksha, 6(1), 53-65. https://doi.org/http://dx.doi.org/10.23887/jeu.v6i1.20267.

Fitriani, R., \& Marlina, M. (2017). Perlindungan Hukum Terhadap Anak Korban Kekerasan Seksual Dalam Rumah Tangga. Jurnal Mercatoria, 2(1). Retrieved from https://ejournal.balitbangham.go.id/index.php/dejure/article/view/1429.

Harahap, A. C. P. (2019). Character Building Pendidikan Karakter. Jurnal Pendidikan Dan Konseling, 9(1), 1-11. https://doi.org/http://jurnal.uinsu.ac.id/index.php/al- 
irsyad/article/view/6732/0.

Hidayah, N. (2015). Penanaman Nilai-Nilai Karakter Dalam Pembelajaran Bahasa Indonesia Di Sekolah Dasar. TERAMPIL: Jurnal Pendidikan dan Pembelajaran Dasar, 2(2), 190-204.https://doi.org/10.24042/terampil.v2i2.1291. Jurnal Pendidikan Dan Pembelajaran Dasar, 2(2), 190-204. https://doi.org/https://doi.org/10.24042/terampil.v2i2.1291.

Ibrahim, I., Kuswidi, I., \& Arfinanti, N. (2020). Development of a Guide to Preparation of Mathematics Questions Based on Higher Order Thinking Skills and Strengthening Character Education for Middle School Teachers. Jurnal Fourier, 9(1). https://doi.org/https://doi.org/10.14421/fourier.2020.91.35-42.

Indiarti, W. (2017). Nilai-Nilai Pembentuk Karakter Dalam Cerita Rakyat Asal-Usul Watu Dodol. Jentera: Jurnal Kajian Sastra, 6(1). https://doi.org/https://doi.org/10.26499/jentera.v6i1.334.

Koesoemadinata, M. I. P. (2018). Visual Adaptation Of Wayang Characters In Teguh Santosa's Comic Art. MUDRA: Jurnal Seni Budaya, 33(3). https://doi.org/https://doi.org/10.31091/mudra.v33i3.544.

Kuswara, K., \& Sumayana, Y. (2020). Apresiasi Cerita Rakyat sebagai Upaya Memperkuat Karakter Siswa dalam Menghadapi Revolusi Industri 4.0. JURNAL BASICEDU, 5(1). https://doi.org/https://doi.org/10.31004/basicedu.v5i1.678.

Mahardika, A. (2017). Penanaman Karakter Bangsa Berbasis Kearifan Lokal Di Sekolah. Pendidikan Kewarganegaraan, $7(2)$. https://doi.org/http://dx.doi.org/10.20527/kewarganegaraan.v7i2.4264.

Mastra, I. N. (2019). Peningkatan Kinerja Guru Dalam Penyusunan Rencana Pelaksanaan Pembelajaran (RPP) Melalui Pendampingan Klasikal Dan Individual Di SD Negeri 26 Ampenan Semester SAtu Tahun Pelajaran 2017/2018. Jurnal Ilmiah Mandala Education, 5(2). https://doi.org/http://dx.doi.org/10.36312/jime.v5i2.755.

Maunah, B. (2015). Implementasi Pendidikan Karakter dalam Pembentukan Kepribadian Holistik Siswa. Jurnal Pendidikan Karakter, 1(1). https://doi.org/https://doi.org/10.21831/jpk.v0i1.8615.

Muhammad, M. (2019). Aspek Perlindungan Anak Dalam Tindak Kekerasan (Bullying) Terhadap Siswa Korban Kekerasan Di Sekolah (Studi Kasus di SMK Kabupaten Banyumas). Journal of Dinamika Hukum, 9(3). https://doi.org/https://doi.org/10.20884/1.jdh.2009.9.3.234.

Mulyanah, Ishak, \& Iqbal. (2018). Penerapan Metode Total Physical Response (TPR) dalam Penguasaan Kosakata Bahasa Inggris Sekolah Dasar (SD). Jurnal Pendidikan Sekolah Dasar, 4(2). https://doi.org/http://dx.doi.org/10.30870/jpsd.v4i2.3855.

Narayani, W. (2019). Pengaruh Model Pembelajaran Nht Berbasis Tri Hita Karana Terhadap Karakter Dan Hasil Belajar IPA. Jurnal Pendidikan Multikultural Indonesia., 2(1). https://doi.org/http://dx.doi.org/10.23887/jpmu.v2i1.20785.

Prastikawati, E. F., Wiyaka, W., \& Budiman, T. C. S. (2021). Pelatihan Penyusunan Soal Bahasa Inggris Berbasis HOTS bagi Guru Bahasa Inggris SMP. Jurnal Pengabdian Masyarakat, 6(1). https://doi.org/https://doi.org/10.30653/002.202161.761.

Ratnawati, Imron, \& Benty. (2018). Manajemen Pendidikan Karakter Peserta Didik Melalui Kegiatan Ekstrakurikuler Pramuka. Jurnal Adminitrasi Dan Manajemen Pendidikan, 1(3).

Rispantyo, Anita Trisiana, S. (2019). Implementasi Pendidikan Karakter Dalam Pendidikan Kewarganegaraan Sebagai Inovasi Pengembangan Di Era Media Digital Dan Revolusi Industri 4.0. Jurnal Global Citizen: Jurnal Ilmiah Kajian Pendidikan Kewarganegaraan, 7(1). https://doi.org/10.33061/jgz.v7i1.3059.

Rosikum, R. (2018). Pola Pendidikan Karakter Religius pada Anak melalui Peran Keluarga. 
Jurnal Kependidikan, 6(2). https://doi.org/https://doi.org/10.24090/jk.v6i2.1910.

Sriyanto, Leksono, \& Harwanto. (2019). Bahan Ajar PPKn Berbasis Karakter dan Literasi Untuk Siswa Kelas IX SMP Al Hikmah Surabaya. Edmotech, 4(2), 130-142. https://doi.org/http://dx.doi.org/10.17977/um039v4i22019p130.

Suhaida, D., \& Fadillah, S. (2019). Media Kajian Kewarganegaraan membentuk karakter siswa. Jurnal Civics: Media Kajian Kewarganegaraan, 16(2), 111-121. https://doi.org/https://doi.org/10.21831/jc.v16i2.21757.

Supraptiningrum, \& Agustini. (2015). Pengembangan Karakter Siswa Melalui Budaya Sekolah di Sekolah Dasar. Jurnal Pendidikan Karakter, 1(2). https://doi.org/https://doi.org/10.21831/jpk.v0i2.8625.

Suryaningtyas, W., Suprapti, E., Solikin, A., \& Shoffa, S. (2014). Implementasi Lesson Study Berbasis Karakter Pada Mata Kuliah Statistika Dasar Dengan Menggunakan Media “Gabuz." Jurnal Pendidikan Dan Ilmu Pengetahuan, 14(1). https://doi.org/http://dx.doi.org/10.30651/didaktis.v14i1.50.

Sutarto, S. (2017). Dampak Pengiring Pembelajaran Pendekatan Saintifik Untuk Mengembangan Sikap Spiritual Dan Sosial Siswa. Jurnal Cakrawala Pendidikan, 36(1), 44-56. https://doi.org/10.21831/cp.v36i1.12792.

Utomo, E. P. (2018). Internalisasi Nilai Karakter Gotong Royong dalam Pembelajaran IPS untuk Membangun Modal Sosial Peserta Didik. Jurnal Teori Dan Praksis Pembelajaran, 3(2), 95-102. Retrieved from http://journal2.um.ac.id/index.php/jtppips/article/view/4821.

Veronika, A. (2019). Implementasi Ajaran Tri Kaya Parisudha Dalam Membangun Karakter Generasi Muda Hindu Di Era Digital. Jurnal PASUPATI, 6(2). https://doi.org/http://dx.doi.org/10.37428/pspt.v6i1.135.

Wahyudin, W. (2018). Optimalisasi Peran Kepala Sekolah dalam Implementasi Kurikulum 2013. Jurnal Kependidikan, 6(2), 249-265. https://doi.org/10.24090/jk.v6i2.1932.

Wiasti, N. M., \& Arjani, N. L. (2021). Perempuan Karir di Bawah Bayang-Bayang Kekerasan dalam Rumah Tangga di Kabupaten Badung: Suatu Analisis Gender. Humanis, 25(1). https://doi.org/https://doi.org/10.24843/JH.2021.v25.i01.p02.

Widiyasanti, M., \& Ayriza, Y. (2018). Pengembangan Media Video Animasi untuk Meningkatkan Motivasi Belajar dan Karakter Tanggung Jawab Siswa Kelas V. Jurnal Pendidikan Karakter, 8(1). https://doi.org/https://doi.org/10.21831/jpk.v8i1.21489.

Wikanengsih, Nofiyanti, \& Permana. (2015). Analisis Rencana Pelaksanaan Pembelajaran (RPP) Mata Pelajaran Bahasa Indonesia (Studi Terhadap Rpp Yang Disusun Guru Bahasa Indonesia Tingkat SMP Di Kota Cimahi. Jurnal Ilmiah P2M STKIP Siliwangi P2M STKIP Siliwangi, 2(1). https://doi.org/https://doi.org/10.22460/p2m.v2i1p106119.170.

Winaya, A. I. M. (2018). Efektivitas Implementasi Model Pembelajaran Tematik Berbasis Tekhnohumanistik dalam Pengembangan Nilai-Nilai Karakter pada Peserta didik SD Dwijendra Denpasar. Jurnal Ilmiah Ilmu Sosial, 4(2). https://doi.org/http://dx.doi.org/10.23887/jiis.v4i2.16524.

Wisnu, \& Komang. (2019). Menanamkan Konsep Catur Paramita Pada Anak Usia Dini Di Lingkungan Keluarga Dan Sekolah. Pratama Widya: Jurnal Pendidikan Anak Usia Dini, 3(2), 41-46. https://doi.org/10.25078/pw.v3i2.737.

Wulandari, A., \& Suparno, S. (2020). Pengaruh Model Problem Based Learning terhadap Kemampuan Karakter Kerjasama Anak Usia Dini. Jurnal Obsesi : Jurnal Pendidikan Anak Usia Dini, 4(2). https://doi.org/https://doi.org/10.31004/obsesi.v4i2.448.

Wuryani, M. T., \& Yamtinah, S. (2018). Textbooks Thematic Based Character Education on Thematic Learning Primary School: An Influence. International Journal of Educational Methodology, 4(2), 75-81. https://doi.org/10.12973/ijem.4.2.75. 
Wuryanti. (2016). Pengembangan Media Video Animasi untuk Meningkatkan Motivasi Belajar dan Karakter Kerja Keras Siswa Sekolah Dasar. Jurnal Pendidikan Karakter, 6(2). https://doi.org/.https://doi.org/ 10.21831/jpk.v6i2.12055.

Wuryanti, U., \& Kartowagiran, B. (2016). Pengembangan Media Video Animasi untuk Meningkatkan Motivasi Belajar dan Karakter Kerja Keras Siswa Sekolah Dasar. Jurnal Pendidikan Karakter, 6(2). https://doi.org/https://doi.org/ 10.21831/jpk.v6i2.12055.

Zuhriyah, M. (2017). Storytelling to Improve Students' Speaking Skill. English Education: Jurnal Tadris Bahasa Inggris, 10(1), 119-134. https://doi.org/https://doi.org/10.24042/ee-jtbi.v10i1.879. 